\title{
THE TEXTBOOK AS CLASSROOM CONTEXT VARIABLE
}

\author{
HEIN P. M. KRAMMER \\ Twente University of Technology, Enschede, The Netherlands
}

\begin{abstract}
To explore the role of the textbook as a context variable in process-product relationships, data on teaching practices and learning outcomes from the IEA Classroom Fnvironment Study in The Netherlands were used. The sample consisted of 50 secondary school mathematics classes and their teachers. Three textbooks were represented in the sample. Data collection included systematic observation of lessons and administration of tests and questionnaires to students and teachers. Nine teaching practices analogous to the distinguishing features of the textbooks were identified, and data relating to these practices were analysed. Four of the teaching practices occurred to different degrees in the three groups of textbook users. The correlations with two leaming outcontes in different groups of textbook users were significantly different for 5 of the 18 cases. These results suggest that the textbook is an important context variable.
\end{abstract}

This study explored the importance of the textbook as a context variable in a correlational process-product study amiong three groups of eighth-grade mathematics teachers. Each group used a different textbook. Two hypotheses were tested in the study: (a) Teachers with different textbooks use different teaching practices, and (b) correlations between teaching practices and student learning outcomes are different for teachers using different textbooks.

In the model that Dunkin and Biddle (1974) used to describe research on teaching, the textbook is mentioned as an aspect of the context with which the teacher has to cope. Individual schools in The Netherlands are almost completely autonomous with respect to their choice of curriculum packages or series of textbooks for mathematics. Recently, a few studies have reported on the circumstances of textbook choice by teachers in The Netherlands (Berkenbosch, 1985; Wolters \& Van HoutWolters, 1985). Most secondary schools lack regulations on textbook choice procedures, but it is common for groups of mathematics teachers to decide on the choice of mathematics textbooks. The main sources for decision are advertising matter and colleagues' opinions. As textbooks stay with a school for a long time after new teachers are appointed, only about half of the teachers have influenced the choice of the textbook they use. Individual teachers cannot escape this situation and must adapt their teaching to the textbook chosen for use in their classes. Thus many teachers (in one study, $84 \%$ ) use supplementary materials written by themselves or copied from other sources. For this reason, the textbook should be considered a context variable.

Context variables are of particular interest if we believe that they influence the effectiveness of the teacher's behavior in the classroom. In the Dunkin-Biddle model, we would say that the context variable influences the relationship between process and product variables. Rigorous proof of such influence is hard to obtain because most context variables, by their very

\footnotetext{
* This study was partly funded by the Stichting Voor Onderzoek van Onderwijs (Foundation for Educational Research) at 's Gravenhage, The Netherlands. The author wishes to express his gratitude to Egbert Warries, Peter van der Sijde, and Jeroen van Merriënboer for their helpful comments and suggestions for revision of this paper.
} 
nature, do not lend themselves to experimental manipulation. In some cases, however, differences in process-product correlations appear together with differences in context. Such contextual effects have been demonstrated for (a) the socioeconomic status of the students' families (Good, Ebmeier, \& Beckerman, 1978; Medley, 1977; Waxman \& Eash, 1983); (b) pupil age and grade (Brophy, Coulter, Crawford, Evertson, \& King, 1975; Evertson, Anderson, Anderson, \& Brophy, 1980; Medley, 1977; Waxman \& Eash, 1983); and (c) subject (Cornbleth \& Korth, 1980; Evertson et al., 1980; Medley, 1977). Gage (1979) organized these context variables into a hypothetical tree structure explicating possible limitations of the generality of process-product research outcomes.

Unfortunately, little empirical research has been undertaken to test our two hypotheses. Most such research has been done in the context of curriculum evaluation. This research generally found low adoption of the teaching practices advised by the developers (Walker, 1976). Yet, it cannot be concluded from these findings that curriculum materials do not strongly influence teaching practices. A study by Tomic (1983) yielded results suggesting that teachers of different textbooks apply different teaching practices. Using a questionnaire, Tomic asked mathematics teachers to report on their class room behavior. Analyses of variance indicated that 10 out of 62 teaching practice variables differed significantly between users of different textbooks.

We hypothesize that the textbook influences not only the frequency of use of specific teaching practices but also the effectiveness of those practices. If a textbook, for instance, provides for much review, reviewing by the teacher may be less effective than it would be if the textbook never reviewed preceding topics.

\section{Method}

\section{Sample}

The population was defined as the teachers in The Netherlands who taught mathematics in an eighth-grade class in a school preparing for the universities and who used one of the three bestknown textbooks. These three textbooks, which shared $90 \%$ of the market, were Getal en Ruimte ("Number and Space", NS), Moderne Wiskunde ("Modern Mathematics", MM), and Sigma (SI).

Seventeen schools participated on a voluntary basis. From comparison with other data, it appeared that the composition of the sample did not deviate substantially from that of the population. The three books appeared to be almost equally represented in the sample $(17,16$, and 17 classes, respectively).

\section{Procedure}

The present study was part of the IEA Classroom Environment Study (Ryan \& Anderson, 1984), an international research project under the auspices of the International Association for the Evaluation of Educational Achievement (IEA). The Classroom Environment Study tried to identify teaching practices associated with high learning outcomes. In The Netherlands, the data, collected in the academic year 1981-82, consisted of systematic observation of eight lessons per teacher by trained observers, administration of questionnaires to teachers and students at the beginning and the end of the school year, and administration of several measures of cognitive and affective outcomes to the students during the school year. All in all, data on more than 200 variables were collected. A brief description of the variables selected for this study is presented below. See Krammer (1984) for details.

\section{Teaching Practice Variables}

Nine variables on teaching practices were selected according to the following procedure. First, information on the textbooks was collected by inspecting the textbooks, interviewing textbook authors, and coding a random sample of problems from the textbooks by trained coders. On the basis of these qualitative and quantitative data, a list of distinguishing features of the textbooks was drawn up, and the textbooks were ordered according to these features (see Table 1). Finally, for each feature an "analogous" teaching practice variable about which information was available was identified (e.g., the teaching practice variable "frequency with which the teacher gives examples of practical applications" was judged to be analogous to the distinguishing textbook feature "number of 
Table 1

Rank Ordering of Textbooks According to Textbook Features"

\begin{tabular}{|c|c|c|c|}
\hline \multirow[b]{2}{*}{ Textbook Feature } & \multicolumn{3}{|c|}{ Textbook } \\
\hline & NS & MM & SI \\
\hline 1. Supplies as aids for diagnosis and remedy & 3 & 1 & 2 \\
\hline 2. Text fragments which organize content & 1.5 & 1.5 & 3 \\
\hline 3. Suitability as a reference book & 2 & 1 & 3 \\
\hline 4. Brushing up prerequisite knowledge & 3 & 1.5 & 1.5 \\
\hline 5. Number of problems with reference to reality & 2 & 3 & 1 \\
\hline 6. Cognitive level of problems and exercises & 1 & 2 & 3 \\
\hline 7. Suitability for conducting seatwork & 3 & 1.5 & 1.5 \\
\hline 8. Suitability for conducting classroom discussion & 1 & 3 & 2 \\
\hline 9. Suitability for conducting different student activities at the same time & 3 & 1.5 & 1.5 \\
\hline 10. Total number of problems and exercises & 3 & 2 & 1 \\
\hline 11. Percentage of guided discovery problems & 3 & 2 & 1 \\
\hline
\end{tabular}

Textbooks are ordered from high (3) to low (1), using the mean order convention if textbooks were judged to be equal.

problems with reference to reality"). If more than one teaching practice variable was analogous to a textbook feature, preference was given to a variable selected from the systematic observation rather than from the teacher's self-report or the students' perceptions. For two textbook features (Numbers 10 and 11 in Table 1), no analogous teaching practice variables could be found. 'T he following list of teaching practice variables was selected (the source of information is given in parentheses, namely, obs = systematic observation, teach $=$ teacher's selfreport, stud = students' perceptions):

1. The amount of remedial help by the teacher to the students (stud)

2. The amount of structuring by the teacher (stud)

3. The frequency of teacher questions requiring reference to books (teach)

4. Brushing up prerequisite knowledge by the teacher (teach)

5 . The frequency with which the teacher gives examples of practical applications (teach)

6 . The frequency of higher cognitive questioning by the teacher (obs)

7. The amount of seatwork by the students (obs)

8. The amount of academic conversation or discussion by or with the students (obs)

9. The number of different student activities occurring at the same time (obs).

\section{Outcome Measures}

Two learning outcome measures were constructed, one cognitive, the other affective. The cognitive measure was based on several tests.
Because the content of the three textbooks differed considerably, it was impossible to construct one final cognitive test having sufficient content validity for all three books. Therefore, several "concluding" tests were administered to each class, one after each topic concerned had been studied. Selection of these tests, from a pool of tests, was based on the content planned by the teacher. In all concluding tests, only those items were counted per class which, according to the teacher's statement on the accompanying questionnaire about opportunity to learn, concerned the subject-matter dealt with. The class average of the proportion of the counted items replied to correctly formed the "concluding result" of the class. The cognitive outcome measure was then calculated as the difference between two standardized scores ( $z$ scores), the first on the concluding test result, and the second on the average class score on the initial cognitive test, which was identical for all classes.

The affective outcome measure was determined on the basis of a 6-item Likert scale in a questionnaire administered to the students at the beginning and end of the school year. These items measured attitude towards mathematical work. The affective outcome measure was calculated as mean difference between the pretest and posttest scores on these scales.

\section{Analysis}

Data were analysed separately for each teaching practice variable. To test the significance of differences in frequency of occurrence 
between users of different textbooks, either an analysis of variance or a Kruskal-Wallis test was carried out. The latter test was chosen if the skewness of the distribution was more than 2.0 in at least one of the groups of textbook users, or the variances were significantly different in the three groups. Because of the exploratory character of this study, the significance level was set at $10 \%$.

To test differences in the relationships between teaching practice variables and learning outcome variables for users of different textbooks, the test for the significance of differences between Pearson product-moment correlations was used. For each combination of a teaching practice variable and a learning outcome variable, six pairwise contrasts were considered (three paired comparisons between textbook user groups, and three comparisons between one textbook user group and the two other groups combined). An effect was considered significant if at least one of the pairwise contrasts was significant at the $3 \%$ level, corresponding to a significance level of $10 \%$ for the overall effect.

\section{Results}

Information on the teaching practices followed in the three groups of textbook users is presented in Table 2. According to an ANOVA or a Kruskal-Wallis test at the $10 \%$ level, four of the nine teaching practices occurred to significantly different degrees, namely, the frequency of higher-order questions, the amount of seatwork, the amount of academic conversation, and the students' perception of remedial help. The probability of this result (4 significant differences at the $10 \%$ level out of 9 cases) indicates a significant overall difference in teaching practice between the three textbook user groups.

Pearson product-moment correlations between teaching practice variables and learning outcome variables are presented in Table 3 . As described above, for each of the 18 cases $(9$ teaching practices $\times 2$ outcomes), six contrasts have been tested. In 5 of the 18 cases a difference in the correlations, significant at the $3 \%$ level, appeared in at least one of the contrasts. This indicates a significant overall difference in correlation between teaching practice and learning outcome for groups of users of different textbooks.

\section{Discussion}

The results indicate that users of different textbooks use different teaching practices and that process-product relationships differ for users of different textbooks. From these results we may infer that the textbook can be an important context variable, one that influences both the occurrence and the relationship-to-outcome of teaching practices.

Table 2

Teaching Practices of Users of Different Textbooks

\begin{tabular}{|c|c|c|c|c|c|c|}
\hline \multirow[b]{2}{*}{ Teaching Practice } & \multicolumn{2}{|c|}{$\begin{array}{c}\text { NS } \\
(n=17)\end{array}$} & \multicolumn{2}{|c|}{$\begin{array}{c}\text { Textbook } \\
\text { MM } \\
(n=16)\end{array}$} & \multicolumn{2}{|c|}{$\begin{array}{c}\text { SI } \\
(n=17)\end{array}$} \\
\hline & M & $\mathrm{SD}$ & M & $\mathrm{SD}$ & M & SD \\
\hline 1. Remedial help & 6.6 & 0.7 & 6.0 & 1.1 & 6.7 & $1.0^{*}$ \\
\hline 2. Structuring & 2.7 & 0.6 & 2.8 & 0.6 & 2.5 & 0.5 \\
\hline 3. Reference-to-book questions & 1.4 & 0.5 & 1.4 & 0.6 & 1.4 & 0.6 \\
\hline 4. Brushing up prerequisites & 5.2 & 1.4 & 5.7 & 1.6 & 4.8 & 1.6 \\
\hline 5. Practical applications & 18 & 0.7 & 2.1 & 0.8 & 1.9 & 0.8 \\
\hline 6. Higher-order questions ${ }^{h}$ & 1.5 & 1.0 & 2.5 & 1.5 & 2.7 & $2.1^{*}$ \\
\hline 7. Seatwork & 0.28 & 0.14 & 0.18 & 0.10 & 0.18 & $0.09^{*}$ \\
\hline 8. Academic conversation' & 0.07 & 0.12 & 0.13 & 0.10 & 0.14 & $0.14^{*}$ \\
\hline 9. Different activities ${ }^{\mathrm{h}}$ & 0.06 & 0.05 & 0.06 & 0.06 & 0.09 & 0.10 \\
\hline
\end{tabular}

"Based on 13 users of textbook MM.

"For this variable a Kruskal-Wallis test was done instead of ANOVA.

${ }^{*}$ Significant difference according to ANOVA or Kruskal-Wallis test with $p<0.10$. 
Table 3

Correlations Between Teaching Practices and Learning Outcomes for Users of Different Textbooks

\begin{tabular}{|c|c|c|c|}
\hline Teaching Practice Variable & $\begin{array}{c}\text { NS } \\
(n=17)\end{array}$ & $\begin{array}{c}\text { Textbook } \\
\text { MM } \\
(n=16)\end{array}$ & $\begin{array}{c}\text { SI } \\
(n=17)\end{array}$ \\
\hline \multicolumn{4}{|l|}{ Cognitive Learning Outcome } \\
\hline 1. Remedial help & -0.06 & 0.56 & $0.00^{*}$ \\
\hline 2. Structuring & 0.03 & 0.03 & -0.02 \\
\hline 3. Reference questions & 0.03 & 0.04 & -0.18 \\
\hline 4. Brushing up prerequisites ${ }^{a}$ & 0.24 & 0.60 & 0.35 \\
\hline 5. Practical applications ${ }^{\mathrm{a}}$ & 0.31 & 0.34 & $-0.56^{*}$ \\
\hline 6. Higher-order questions & 0.21 & 0.21 & 0.40 \\
\hline 7. Seatwork & -0.19 & -0.09 & 0.08 \\
\hline 8. Academic conversation & 0.30 & -0.31 & -0.03 \\
\hline 9. Different activities & -0.12 & -0.50 & -0.16 \\
\hline \multicolumn{4}{|l|}{ Affective Learning Outcome } \\
\hline 1. Remedial help & -0.04 & 0.49 & $0.57^{*}$ \\
\hline 2. Structuring & -0.05 & 0.10 & 0.26 \\
\hline 3. Reference questions & 0.62 & -0.39 & $0.29 *$ \\
\hline 4. Brushing up prerequisites ${ }^{a}$ & -0.10 & 0.27 & 0.14 \\
\hline 5. Practical applications ${ }^{\mathrm{a}}$ & 0.30 & 0.07 & -0.13 \\
\hline 6. Higher order questions & 0.10 & 0.00 & 0.06 \\
\hline 7. Seatwork & -0.14 & -0.34 & 0.20 \\
\hline 8. Academic conversation & -0.20 & -0.23 & -0.37 \\
\hline 9. Different activities & -0.42 & -0.50 & $0.22^{*}$ \\
\hline
\end{tabular}

${ }^{a}$ Based on 13 users of textbook MM.

* Significant difference between correlations for at least one contrast, with $p<0.03$.

With respect to the occurrences, we were able to find plausible explanations in terms of the textbook characteristics. For example, the textbook NS differs from the other two in that much seatwork is recommended by its authors and made easy through the language and the type of questions used in the book. Furthermore, its authors tried to avoid high-level questions that could create difficulties for students during seatwork or that would evoke classroom discussion. It is little wonder that in the classes where this textbook was used, seatwork occurred more often, and higher-order questions and academic conversation occurred less often, than in the other classes. Whether the textbook caused the differences cannot be decided on the basis of these data; an alternative explanation could be that teachers choose a textbook that resembles their preferred teaching style.

Although the significant differences obtained can be explained by the simple rule: "Teaching practices resemble the textbook characteristics," it was difficult to understand why additional significant differences were not found. For example, the textbook MM offers many more practical application problems than the other two textbooks. (The percentage of problems relating to reality is $3.6 \%$ for $\mathrm{NS}, 8.9 \%$ for MM and $0.0 \%$ for SI.) Why then do the teaching practices not accord with this fact? Perhaps teacher self-report is an invalid or insensitive measuring device for the present research question. (Recall that three of the four variables that yielded significant differences in occurrence between textbook user groups were based on classroom obscrvation.) If so, the study should be replicated using observational data only.

It should be emphasized that this relation between teaching practices and textbook characteristics does not conform to a conception of teacher behavior as rational. Such a conception would lead one to expect teaching practices to complement or to correct for, and not to resemble, the textbook. Our results do not reflect any such complementarity.

As to the association of teaching practices with outcomes, no one or two simple rules could be formulated to explain all significant findings in terms of the textbook characteristics. It seems that apparently effective teaching prac- 
tices in some cases resemble the textbook style (as with practical applications), and in other cases they deviate from it (as with remedial help). Furthermore, it seems that student activities for which the textbook is not well suited should sometimes be avoided (as with reference questions) and in other cases be stressed (as with different activities in the case of textbook Sigma). Clearly, further theoretical and empirical studies are needed to explain how the textbook influences process-product relationships.

Although this study was not primarily directed towards the identification of teaching practices which are effective irrespective of the textbook used, the results suggest two such teaching practices: brushing up prerequisite knowledge and higher-order questioning. The latter variable is well known in process-product research. The former is clearly related to Gagné's theory on internal conditions of learning (Gagné, 1977). Perhaps Gagné's "instructional events" should reccive more attention in process-product research.

\section{References}

Berkenbosch, J. (1985). De keuze van een nieuwe methode (The choice of a new textbook series). In Ontwikkelingen. rond schoolboeken in Nederland (Developments in textbooks in The Netherlands). Zoetermeer: Adviesgroep Leermiddelen.

Brophy, J. E., Coulter, C. L., Crawford, W. J., Evertson, C. M., \& King, C. E. (1975). Classroom observation scales: Stability across time and context and relationships with student learning gains. Journal of Educational Psychology, 67, 873-881.

Cornbleth, C., \& Korth, W. (1980). Context factors and individual differences in pupil involvement in learning activity. Journal of Educational Research, 73, 318-323.

Dunkin, M. J., \& Biddle, B. J. (1974). The study of teaching. New York: Holt, Rinehart, \& Winston.
Evertson, C. M., Anderson, C. W., Anderson, L. M., \& Brophy, J. E. (1980). Relationships between classroom behaviors and student outcomes in junior high mathematics and English classes. American Educational Research Iournal, 17, 43-60.

Gage, N. L. (1979). The generality of dimensions of teaching. In P. L. Peterson \& H. J. Walberg (Eds.), Research on teaching: Concepts, findings and implications. Berkeley, CA: McCutchan.

Gagné, R. M. (1977). The conditions of learning (3rd ed.). New York: Holt, Rinehart, \& Winston.

Good, T. I., Ebmeier, H., \& Beckerman, T. (1978). Teaching mathematics in high and low SES classrooms: An empirical comparison. Journal of Teacher Education, 29, 85-90.

Krammer, H. P. M. (1984). Leerboek en leraar: Een proces-product-onderzoek in 50 klassen op havo en vwo naar verbanden tussen leerboekkenmerken onderwijsactiviteiten en leerresultaten voor wiskunde (Textbook and teacher: A process-product investigation in 50 secondary school mathematics classes on relationships between textbook characteristics, teaching practices, and learning outcomes). The Hague: S.V.O.

Medley, D. M. (1977). Teacher competence and teacher effectiveness: $A$ review of process-product research. Washington, DC: American Association of Colleges for Teacher Education.

Ryan, D.W., \& Anderson, L.W. (1984). Rcthinking research on teaching: Lessons learned from an international study. Evaluation in Education, 8, 83-178.

Tomic, W. (1983). Wiskunde-onderwijs, context en onderwijsactiviteiten (Mathematics education, context, and teaching practices). Enschede: Twente University of Technology, Department of Education.

Walker, D. F. (1976). Toward comprehension of curricular realities. In L.S. Shulman (Ed.), Review of Research in Education, 4. Itasca, IL: Peacock.

Waxman, H. C., \& Eash, M. J. (1983). Utilizing students' perceptions and context variables to analyze effective teaching: A process-product investigation. Journal of Educational Research, 76, 321-325.

Wolters, B., \& Van Hout-Wolters, B. (1985). De docent over het leerboek: Een onderzoek naar problemen, plaats en functie (The teacher about the textbook: A study on problems, places and function). In Ontwikkeling rond schoolboeken in Nederland (Developments in textbooks in The Netherlands). Zoetermeer: Adviesgroep Leermiddelen.

Received 16 August $1985 \square$ 